\title{
DEPLETION OF DEIONIZER RESIN IN AN SRP REACTOR SYSTEM
}

\author{
E. W. Baumann
}
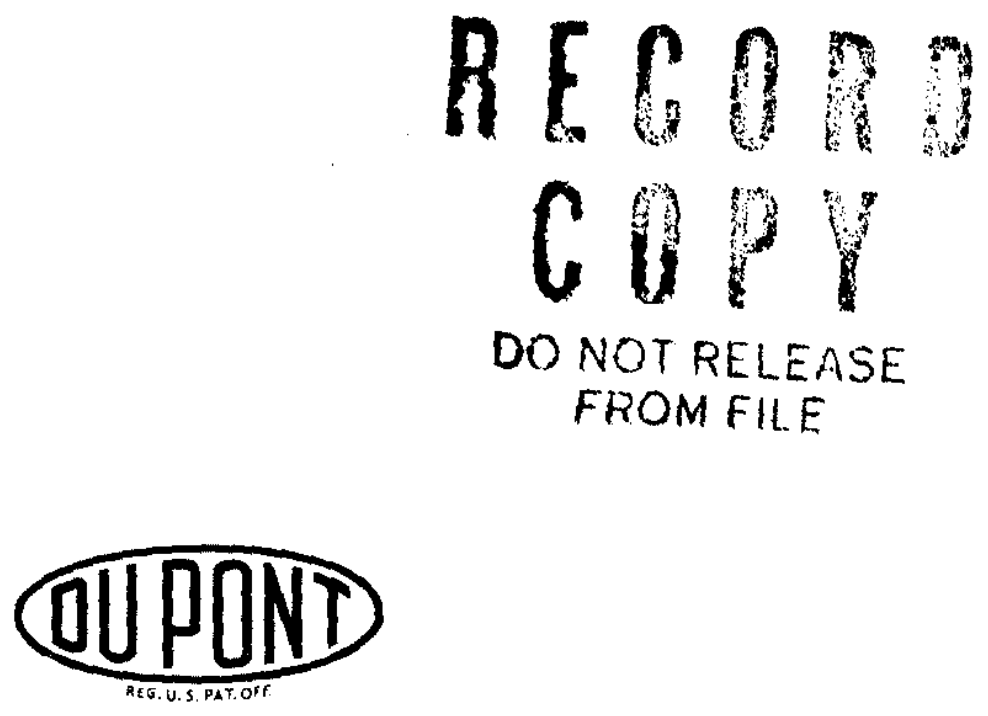

Savannah River Laboratory Aiken, South Carolina 


\section{LEG A L NOTICE}

Th1s report was prepared as an account of Government sponsored work. Nelther the United States, nor the Commission, nor any person acting on behalf of the Commission:

A. Makes any warranty or representation, expressed or $1 \mathrm{mplied}$, with respect to the accuracy, completeness, or usefulness of the information contained in this report, or that the use of any information, apparatus, method, or process disclosed in this report may not infringe privately owned rights; or

B. Assumes any liablities with respect to the use of, or for damages resulting from the use of any information, apparatus, method, or process disclosed in this report.

As used in the above, "person acting on behalf of the Commission" includes any employee or contractor of the Commission, or employee of such contractor, to the extent that such employee or contractor of the Commission, or employee of such contractor prepares, disseminates, or provides access to, any information pursuant to his employment or contract with the Commission, or his employment with such contractor.

Printed in USA. Price $\$ 1.00$

Avallable from the Clearinghouse for Federal Sclentiflc

and Technical Information, National Bureau of Standards,

U. S. Department of Commerce, Springfield, Virginia 


\title{
DEPLETION OF DEIONIZER RESIN
}

\section{IN AN SRP REACTOR SYSTEM}

\author{
by
}

Elizabeth W. Baumann

$$
\text { Approved by }
$$

E. L. Albenesius, Research Manager Analytical Chemistry Division

\section{August 1965}

\footnotetext{
E. 1. DU PONT DE NEMOURS \& COMPANY

SAVANNAH RIVER LABORATORY

AIKEN, SOUTH CAROLINA

CONTRACT AT(07-2).1 WITH THE

UNITED STATES ATOMIC ENERGY COMMISSION
} 


\begin{abstract}
An axial core section was removed from a depleted deionizer from an SRP reactor system, and the ion exchange resins were examined for absorbed 1ons, retained solids, and residual and regenerable exchange capacity. Total depletion of the initial capacity of the cation exchange resin was $60 \%$ and that of the anion exchange resin was 90\%. Destruction of exchange sites by radiation and absorption of resin degradation products accounted for $30 \%$ of the depletion of each resin.
\end{abstract}




\section{CONTENTS}

$\underline{\text { Page }}$

Introduction

Summary

Discussion

Description of System

Experimental Procedure

Sampling the Resin

Examining the Resin

Results

Mixed Resin

Individual Resins

Discussion of Results

Acknow ledgment

References

\section{LIST OF TABLES AND FIGURES}

$\underline{\text { Table }}$

I History of Defonizer

7

II Sol1ds Filtered on Resin

Figure

I Tool for Sampling Delonizer

2 Characterization of Mixed Resin

3 Pattern of Depletion of Resins 


\section{DEPLETION OF DEIONIZER RESIN \\ IN AN SRP REACTOR SYSTEM}

\section{INTRODUCTION}

The examination of used resins is an important part of the study of the performance of delonizers in the heavy water purification system of Savannah River reactors. Such examination provides information about the ionic content of the heavy water moderator and the factors that contribute to delonizer depletion. Determination of the ionic content of moderator from ions concentrated on the resin supplements direct analysis of the moderator and establishes that major Ionic impurities have been recognized. Investigation of the factors causing resin depletion indicates whether maximum usage is obtained from the deionizers, which are discarded when spent.

Most resins examined previously were obtained from a "miniature purification system", which consisted of small ion exchange columns in a reactor loop. $(1,2)$ These resins provided good information about lons removed from moderator, but they could not provide information that directly corresponded with Plant operating conditions. In particular, indications that process resins were degraded during service, perhaps by radiation damage( 3 ), could not be confirmed by testing in the small system. Knowledge of the condition of resin that had been used in the reactor purlfication system was therefore needed.

This report describes the sampling and examination of radioactive spent resin from a production deionizer and defines factors that contributed to depletion of the avallable exchange sites of the resin.

\section{SUMMARY}

An axial core of resin from a spent deionizer of a Savannah River production reactor was sampled with a speclally designed tool. The cation and anion exchange resins were examined for absorbed lons and retalned solids, and for evidences of resin degradation.

Total depletion of the initial capacity of the cation resin was $60 \%$, while depletion of the anion resin was 90\%. The resin depletion was attributed to the following mechanisms: (1) destruction of exchange sites by radiation, (2) absorption of degradation products of the resins, and (3) absorption of ions from the moderator. 
Depletion of exchange capacity by the combination of mechanisms (1) and (2) amounted to 30\% of the inftial capacity for both cation and anion resins. An additional 30\% of the initial capacity of the cation resin was depleted by absorption of cations from the moderator; one-half of this loss in capacity was due to the absorption of $\mathrm{Al}^{3+}$ that was probably produced when solid alumina filtered from the moderator was dissolved by the acid resin. These alumina particles, less than 2 microns in diameter, amounted to about 0.5 wt $\%$ of the resin. Anions, chiefly $\mathrm{NO}_{3}^{-}$and $\mathrm{DCO}_{3}^{-}$, absorbed from the moderator, occupied $60 \%$ of the initial exchange sites of the anion resin.

These results show that the deionizer systems are being operated under favorable conditions; however, some improvement in the service life of the resin could be realized if ion exchange materlals with greater radiation resistance were avallable.

\section{DISCUSSION}

\section{DESCRIPTION OF SYSTEM}

The chemistry and the purification of SRP heavy water moderator has been described in detall elsewhere. $(4,5)$ The moderator contains approximately $10^{-5} \mathrm{M} \mathrm{DNO}_{3}(\mathrm{pD}=5)$ added to inhibit corrosion of aluminum components, plus suspended alumina and iron oxides, radionuclides from fission and neutron activation, and miscellaneous ionic impurities.

Table I gives the history of the delonizer that was sampled. The resin was a mixture with a nominal anion-to-cation equivalent ratio of $2: 1$. The anion exchange resin is of the quaternary ammonium type, origlnally in the $O D^{-}$form. The cation exchange resin is of the sulfonic acid type, originally in the $D^{+}$form.

\section{EXPERIMENTAL PROCEDURE}

\section{Sampling the Resin}

The delonizer sample was believed to be representative of resin at the end of 1 ts service in the reactor system. The delonizer was still filled with heavy water when sampled and had undergone no treatment after it was taken off-line. The delonizer was not sampled until three months after it was removed from reactor service, to reduce radiation exposure to personnel during sampling and examination. 
History of Deionizer

$\begin{array}{ll}\text { Length of service } & 85 \text { days } \\ \text { Throughput } & 6.3 \times 10^{\circ} \text { gallons }\end{array}$

Average composition of feed

Radioactivity (2-hr decay, beta count of evaporated mount, counting efficlency $5.7 \%$ with RaD-RaE standard) $250,000 \mathrm{c} / \mathrm{m} / \mathrm{mI}$ pD

5.1

Conduct1vity

$2.4 \mu \mathrm{mhos} / \mathrm{cm}$

In1tia: Resin (Resins mixed in delonizer):

\begin{tabular}{lccc} 
& $\begin{array}{c}\text { Cation Exchange } \\
\text { Resin }\end{array}$ & $\begin{array}{c}\text { Anion Exchange } \\
\text { Resin }\end{array}$ \\
\cline { 2 - 2 } $\begin{array}{l}\text { Pounds of molst resin } \\
\text { Exchange capac1ty, meq/mI }\end{array}$ & 250 & 846 \\
$\begin{array}{l}\text { Exchange capacity, meq } / 8 \text { dry resin } \\
\quad \text { (used in calculations for Figure 2) }\end{array}$ & 4.9 & 1.1 \\
\end{tabular}

A core of resin along the vertical axis of the delonizer was obtained by the specially designed sampler shown in Figure 1. This all aluminum tool consisted of a central rod with spacers, covered by a removable sheath. In the sampling operation, the sheathed sampler was inserted to the bottom of the resin bed and the sheath was withdrawn to allow resin to enter the sampling spaces. The sheath was then replaced and the assembly was removed from the deionizer. Excess water from the resin sample was allowed to drain back into the delonizer.

The sampler was placed in a shipping contalner and brought to the laboratory where it was dismantled. E1ght samples were recovered sequentially from between the spacers as the sheath was withdrawn, as shown in Figure 1.

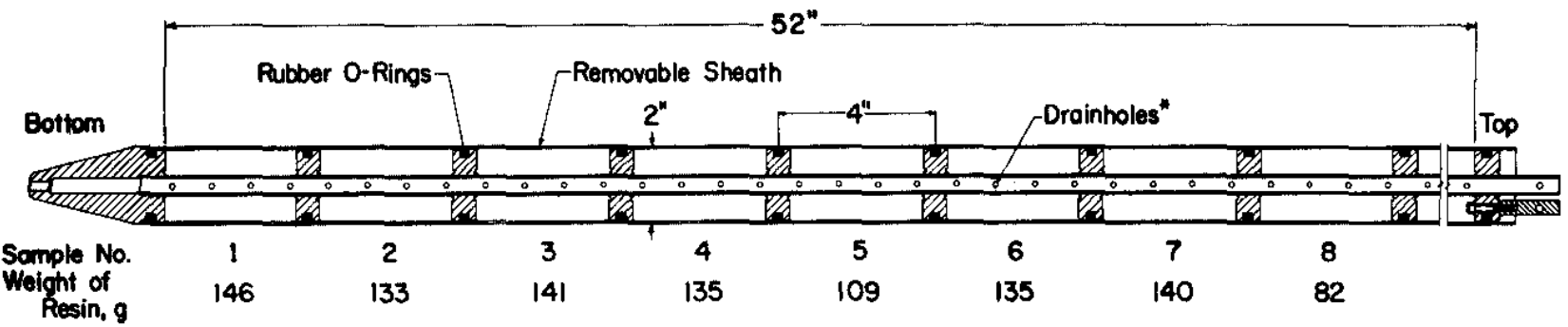

"Covered by Nylon Mesh

FIG. I TOOL FOR SAMPLING DEIONIZER 


\section{Examining the Resin}

The mixed resin was treated by methods previously described. $(1,2,8)$

Separation of Filtered Solids - The resin samples were backwashed and the washings were filtered on a 0.45 -micron "Millipore"* filter. The residue was dried over $\mathrm{CaSO}_{4}$.

Separation of Cation and Anion Resin Components - The initial separation was made by water flotation. This separation was difficult because the differences in density and appearance were slight. A final separation was made in glycerine to obtain a clean cation resin fraction.

Analysis of Resins - The exchange capaclties and the 1ons absorbed were determined on salt elutriates of the separated resin components.

\section{RESULTS}

\section{Mixed Resin}

Appearance - The resin was uniformly dark brown. The anion exchange resin, originally yellow, had darkened during service, due to radiation exposure. The physical state of the resin was good; the spherical beads were intact and firm.

Radioactivity - Figure 2 shows dose rates for the resins as they were removed from the sampler. A large proportion of the activity was shielded out by 3/8-1nch transparent plastic, the "closed window" readings. The cation exchange resin contained most of the radioactivity.

Filtered Solids - During the initial backwashing of the resin with water, finely divided material that had been retained by the resin was released. The water was foamy, indicating the presence of some organic material. With continued washing of the resin, the water clarified rapidiy.

Figure 2 shows the distribution of the solids along the column. The apparent concentration of solids at the center of the delonizer was not expected. Results of examination of the solids are given in

*Trademark of M1lipore Filter Corporation, Bedford, Mass. 
A. Radiation Level

B. Filtered

Solids

Content

C. Composition of Resin Mixture
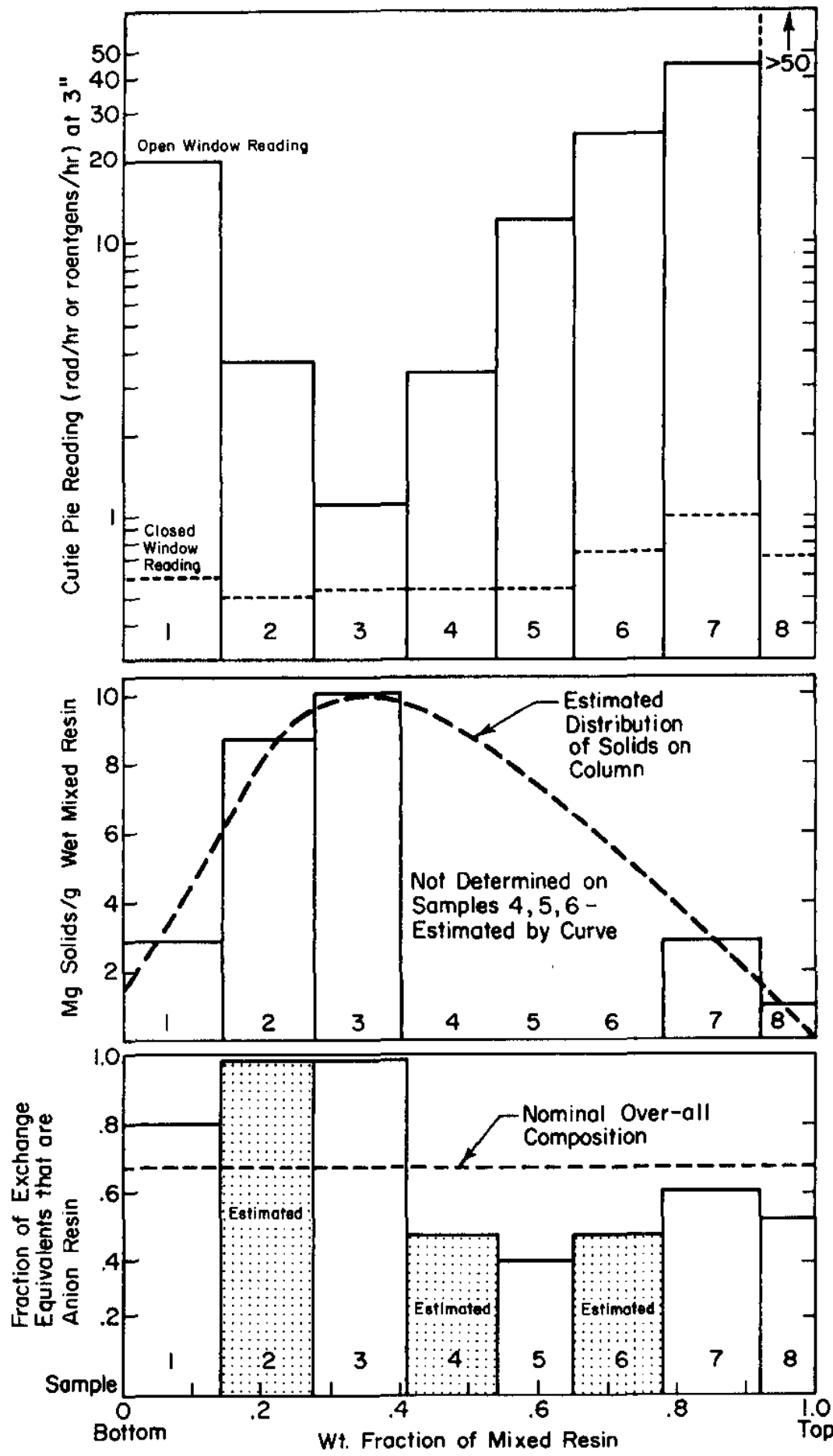

FIG. 2 CHARACTERIZATION OF MIXED RESIN 
Table II. The material was mostly alumina, which is always found in water from this reactor system. The maximum particle size is limited by a 5 -micron filter that removes the larger particles upstream of the deionizer. The resins thus supplement the filters by retaining very small particles, although their filtering action is not quantitative. The total amount of solids held $(0.5$ wt $\%)$ was slightly less than the 0.8 wt $\%$ observed in the earlier miniature purification tests; however, the present cross-sectional flow was nearly twice that of the earlier tests.

\section{$\underline{\text { TABLE II }}$}

\section{Solids Filtered on Resin}

Amount

\begin{tabular}{|c|c|}
\hline Estimated average concentration & $\begin{array}{l}5 \mathrm{mg} / \mathrm{g} \text { wet mixed resin } \\
(0.5 \text { wt } \%)\end{array}$ \\
\hline $\begin{array}{l}\text { Corresponding total amount } \\
\text { in delonizer } \\
\text { vature }\end{array}$ & $5.51 \mathrm{~b}$ \\
\hline $\begin{array}{l}\text { Particle size range, estimated } \\
\text { from electron photomicrographs }\end{array}$ & $<0.01$ to $2 \mu$ \\
\hline$x$-ray diffraction & $\begin{array}{l}\mathrm{B-Al}{ }_{2} \mathrm{O}_{3} \cdot 3 \mathrm{H}_{2} \mathrm{O} \\
\text { (Not too well crystallized) } \\
\text { No other crystalline com- } \\
\text { ponents }\end{array}$ \\
\hline $\begin{array}{l}\text { CI content (by neutron activa- } \\
\text { tion method) }\end{array}$ & $360 \mathrm{ppm}$ \\
\hline
\end{tabular}

The chloride content of the alumina is similar to that usually found in alumina from the SRP reactor systems.

Composition of Resin Mixture - The composition of the original resin mixture was calculated by determining the total number of exchange equivalents of each resin in the mixture, and correcting for degradation by a factor obtained from analysis of the individual resins. Compositions of samples 2,4 , and 6 were estimated from visual observation and the nominal over-all composition of the deionizer mixture.

As shown in Figure 2, the mixture along the column was markedly nonuniform. Samples 2 and 3 contalned practically no cation resin. 
Individual Resins

Figure 3 illustrates the pattern of depletion of cation and anion resin exchange capacity for each sample along the length of the deionizer. Fractional depletion of the column as a whole by absorption of lons and by degradation is also given; the nonuniformity of the mixture has been taken into account.

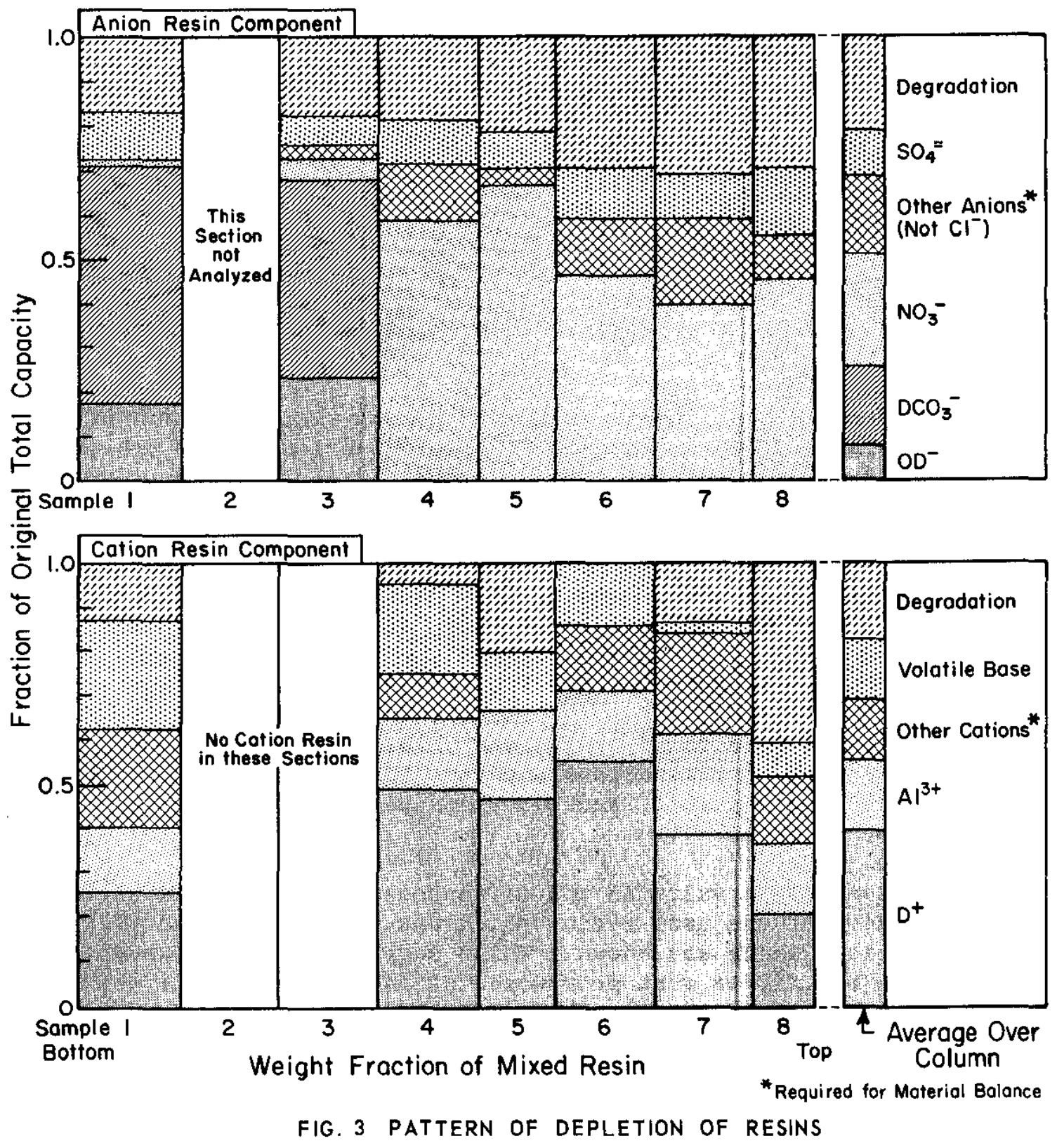




\section{Anion Res 1n}

$O D^{-}$- Less than $10 \%$ of the anton exchange capacity of the column remained in the $\mathrm{OD}^{-}$form; this residual was located at the bottom of the column.

$\mathrm{DCO}_{3}^{-}$- Blcarbonate accounts for nearly $20 \%$ of the total exchange capacity. Its source is not known with certainty. A small amount of $\mathrm{CO}_{2}$ may be absorbed from the air by the alkaline resin during delonizer preparation. However, most of the $\mathrm{CO}_{2}$ is probably produced during service from radiolysis of organic material elther within the delonizer or in the moderator. Displacement of $\mathrm{DCO}_{3}^{-}$by $\mathrm{NO}_{3}^{-}$occurs as would be predicted from selectivity of resin for these ions.

$\mathrm{NO}_{3}^{-}$- Nitrate, from nitric ac1d added to the moderator, is the major exhausting 1on at the top of the column. It accounts for about 25\% of the total anion exchange capac1ty. This amount of $\mathrm{NO}_{3}^{-}$, considered as $\mathrm{DNO}_{3}$, corresponds to an average $\mathrm{pD}$ of 5.2 in the original moderator. Reasonable agreement of this value with the $\mathrm{pD}$ of 5.1 indicated from process data confirms that nitric acid is the principal acidifier.

$\mathrm{Cl}^{-}$- The resin contained less than one equivalent per cent of $\mathrm{Cl}^{-}$, which corresponds to an average $\mathrm{Cl}^{-}$concentration of $<10 \mathrm{ppb}$ in the moderator during the period of operation.

SO $\overline{4}$ - Sulfate occuples about $10 \%$ of the exchange capacity. This ion is considered to have come from cation resin degradation rather than from 1mpurities in the moderator because it is uniformly distributed throughout the bed. Had it been collected from the moderator, it would have been concentrated at the top of the bed because of the preference of the resin for this divalent anion.

Other Antons - Th1s value, which was obtained by difference, reflects uncertainty of the varlous analyses and also suggests that small amounts of other anions, such as chromates, manganates, or aluminate, were present.

Degradation - This value is the difference between the total exchange capac1ty of the used resin, which was determined, and the original capacity, which was known. While degradation is apparent throughout the bed, it is most pronounced at the top where the most severely degrading radiation environment would have been encountered. The over-all degradation of the resin corresponds to about $20 \%$ of the total exchange capacity. 


\section{Cation Resin}

$\underline{D}^{+}$- Nearly $40 \%$ of the orlginal exchange capacity remained in the deuterium form. Since cationic contaminants in significant quantities do not occur in this acid moderator, exhaustion of the cation resin was not expected.

$\mathrm{Al}^{3+}$ - Aluminum ion accounts for $15 \%$ of the resin depletion and corresponds to an average $\mathrm{Al}^{3+}$ concentration in original moderator of about $10^{-8}$ molar, which is approximately the solubility of aluminum hydroxide. The depletion pattern with the aluminum ion distributed uniformly along the length of the column suggests, however, that aluminum did not come from soluble lons, but rather that it was absorbed by dissolution of the insoluble alumina by the resin, by the reaction

$$
1 / 2 \mathrm{Al}_{2} \mathrm{O}_{3} \cdot 3 \mathrm{H}_{2} \mathrm{O}+3 \mathrm{HRes} \rightarrow \mathrm{AlReS}_{3}+3 \mathrm{H}_{2} \mathrm{O}
$$

Volatile Base - Volatile base, e.g., ammonia or trimethylamine, is presumed to be a product of anion resin degradation. Since in the present mixture cation resin is a minority component that absorbs the degradation product of a majority component, distribution of volatile base 1s strongly affected by the nonuniformity of the mixture. At the bottom of the column, where the proportion of anion resin was abnormally high, a large amount of volatile base was found. The skewness of the distribution toward the bottom of the column suggests that volatile base may have leaked from the column during service.

Other Cations - The 15\% listed as other cations reflects the uncertainty of analyses as well as the probable presence of other cations, such as $\mathrm{Mg}, \mathrm{Ca}$, and $\mathrm{Fe}$.

Degradation - As with the anion resin, degradation represented the difference between the total exchange capacity found and that of the orlginal resin. The degradation pattern of the cation resin is somewhat erratic. At the top of the column the total exchange capacity was only $60 \%$ that of the original resin. This very large reduction in exchange capacity at the top of the bed was attributed to damage from oxidizing conditions coupled with the strong radiation dose, primarily from ${ }^{24} \mathrm{Na}$ which was continually collecting and decaying in this zone.

\section{DISCUSSION OF RESULTS}

The service life of the delonizer was limited by a $90 \%$ depletion of the anion resin. This high degree of exhaustion is in line with expectations for mixed-bed performance; however, only about $60 \%$ of the anion resin capacity was actually used for delonization of reactor 
moderator. Of the $60 \%$, less than half was used in removal of nitrate, the only anion deliberately maintalned in the moderator. The impurity, $\mathrm{DCO}_{3}^{-}$, accounted for a large proportion of the remalnder. Resin degradation accounted for the other $30 \%$ depletion. The exchange capacity of the anion resin was reduced by loss of exchange sites and by absorption of $\mathrm{SO}_{4}^{-}$, a degradation product of the cation resin.

The total depletion of cation exchange capacity was about 60\%. of this, less than $15 \%$ was attributed to 1ons in the feed; dissolution of alumina by the resin accounted for another 15\%. The remaining 30\% was attributed to resin degradation.

The cause of the resin degradation has been attributed to radiation damage $(3)$ since these resins accumulate a large dose from ${ }^{24} \mathrm{Na}$ removed from the moderator. This nuclide, produced by the reaction ${ }^{27} \mathrm{AI}(n, \alpha)$ ${ }^{24} \mathrm{~N} \varepsilon$, is indigenous to reactor systems containing aluminum and hence the radiation dose encountered by the resins in this system is substantially higher than in reactor systems that contain no aluminum. The presence of $10^{-5} \mathrm{M} \mathrm{DNO}_{3}$ and $1-5 \mathrm{ppm} \mathrm{D}_{2} \mathrm{O}_{2}$ also contribute to a degrading environment, but their contribution is belleved to be minor compared to that from the radiation.

Low usage of the bed for removal of lons from the moderator suggests the possibility of improvement, but changes that have been considered appear less practical or economical than allowing resin exhaustion from extraneous sources to proceed. The anion resin content of the bed is currently twice the cation resin; further increase in the proportion of anion resin would afford only a small increase in anion capacity and furthermore might compromise complete removal of cations. In the present instance, the nonuniformity of the mixture may have resulted in localized regions of inefficlent delonization; more uniform mixtures are ordinarily attalned. A process for reducing radiation dose by removing radioactivity upstream of the bed, e.g., by inorganic exchangers that are not subject to radiation damage, does not appear practical at this writing. Some improvement in service life of the resin could be realized if fon exchange materlals with greater radiation resistance were avallable. Problems involved in scavenging dissolved $\mathrm{CO}_{2}\left(\mathrm{DCO}_{3}^{-}\right)$by chemlcal stripping of $\mathrm{CO}_{2}$ from the blanket gas appear to outweigh the possible advantage to be gained.

\section{ACKNOWLEDGMENT}

The sampling tool was designed by T. S. McMllian of the Savannah River Laboratory. The resin sample was obtained through the joint efforts of personnel from the Works Technical Department and the Production Department of the Savannah River Plant. 


\section{REFERENCES}

1. E. W. Baumann. Miniature Purification Progress Report. I. Description of Equipment, Tests $\mathrm{Ia}$, Ib, and II. USAEC Report DP-678, E. I. du Pont de Nemours \& Co., Savannah River Laboratory, Aiken, S. C. (1962).

2. E. W. Baumann. Ib1d. II. Tests III through VI. DP-806 (1962).

3. E. W. Baumann. Radiolysis of Ion Exchange Resins Used in the Purification Systems of Savannah River Reactors. USAEC Report DP-977, E. I. du Pont de Nemours \& Co., Savannah River Laboratory, Aiken, S. C. (1965), and paper presented at the 147th National Meeting of the American Chemlcal Soclety, Philadelphia, Pa., Apr11 6-10, 1964.

4. F. B. Longtin. "Impurlties in Moderator of Savannah River Plant Reactors," paper presented at the 147th National Meeting of the American Chemical Soclety, Philadelphia, Pa., April 6-10, 1964.

5. G. N. Flannagan and R. F. Anderson. "Quality Control of Moderator in Savannah River Plant Reactors." Ibld.

6. E. W. Baumann. Analys1s of Used Ion Exchange Resins. USAEC Report DP-218, E. I. du Pont de Nemours \& Co., Savannah River Laboratory, Aiken, S. C. (1957). 